\title{
Importance of Micro Minerals in Reproductive Performance of Farm Animals
}

\author{
Sandeep Uniyal $^{1 *}$, K. Ashwin ${ }^{1}$, Alok Mishra ${ }^{1}$, Jatin Kumar Sahoo ${ }^{1}$ and Varsha Paladan ${ }^{2}$ \\ ${ }^{1}$ Division of Animal Nutrition, ICAR-IVRI, Izatnagar, Bareilly, U.P -243122, India \\ ${ }^{2}$ Veterinary Bacteriology Division, ICAR-IVRI, Izatnagar, Bareilly, U.P, India
}

*Corresponding author

\begin{abstract}
A B S T R A C T
Keywords

Health, reproductive performance Micro minerals, Enzymes, Antioxidant

Article Info

Accepted:

26 June 2018

Available Online:

10 July 2018

Micro minerals are those which are required in minute amount $(<100 \mathrm{mg} / \mathrm{Kg} \mathrm{DM})$ for optimum health and reproductive performance of animals. Various minerals (copper, selenium, manganese, iodine, zinc, and chromium) can influence reproductive performance of animals. It has been suggested that deficiency of micronutrients alter reproductive performance of animals by reducing the activity of rumen microflora, reduction in enzyme activity affecting energy and protein metabolism, synthesis of hormones, antioxidants function and the integrity of rapidly dividing cells within the reproductive system. Most of the feeds and fodder available in India are deficient in one or more micro elements so there is need of supplementation of micro minerals in the ration of farm animals either in the form of mineral mixture or based on the status of soil, feed and fodder of particular region as an area specific mineral mixture.
\end{abstract}

\section{Introduction}

Bennetts and Chapman (1937) were the first who established the link between nutrition and reproduction they found that swayback in lambs occur as a result of deficiency of copper. Micro minerals deficiency most commonly occurs in high production animals ultimately leading to poor reproductive performance. These minerals are required in minute amount and excess feeding of some of these may show toxicity symptoms. Twenty two micro minerals are required for optimum reproductive health of farm animals the important one includes copper, cobalt, manganese, selenium, iodine, zinc, chromium. These minerals are important component of various metallo- enzymes, enzyme cofactors and some of them are integral part of enzymes related to neutralization of reactive oxygen species (ROS) and thereby prevent free radical induced damage of lipids membranes. Some of these are component of hormones and thus play important role in metabolism of macromolecules (carbohydrate, protein and nucleic acid) and any alteration in the level of these minerals may affect the production of reproductive and other hormones. Low level of these micro minerals in the ration may affect embryonic development, post-partum 
recovery and over all fertility in the female animals and in male animals it may change spermatogenesis and reduce libido. Most of the unconventional feeds are deficient in micro minerals and are likely to accentuate reproductive problems.

\section{Selenium (Se)}

Selenium is an essential trace mineral and plays an important role in various biological reactions like antioxidant defense by the virtue of the important component of an enzyme glutathione peroxidases and selenoproteins (Allmang and Krol, 2006) it also required for optimum fertility in both males and females, conversion of thyroid hormone in to active form and immunomodulation (Spallholz, 1990) requirement selenium is generally very low 0.1-0.3 ppm for most of the species. Se occurs in inorganic and organic forms in nature. Inorganic form found as selenite $\left(\mathrm{Se}^{4+}\right)$, selenate $\left(\mathrm{Se}^{6+}\right)$, and selenide $\left(\mathrm{Se}^{2-}\right)$ and these forms mainly selenite or selenite are obtained by plants from soil to synthesize Secontaining amino acids. If soils is deficient in Se results in decrease level of $\mathrm{Se}$ in plants. Therefore, the supplementation of $\mathrm{Se}$ in animal feed is necessary in areas where levels of soil Se are low. Selenium and vitamin E exert sparing effect on each other and both are having potent antioxidant function and protect biological system from oxidative degradation there by improve reproductive potential of animals In early studies it was shown that selenium and vitamin $\mathrm{E}$ injections reduced the incidence of retention of fetal membrane it was also observed that supplementation of selenium with vitamin $E$ reduces the incidence of metritis and cystic ovaries when administered prepartum. Selenium in males essential for normal spermatozoa development it is incorporated in the sperm mitochondria capsule and may thus affect the behavior and function of the spermazoon. Moeini et al., (2009) reported that supplementation of 20-40 $\mathrm{ml}$ of selenium and vitamin $\mathrm{E}$ injection $(0.5$ $\mathrm{mg}$ Se and 50 IU of DL alpha tocopheryl acetate $/ \mathrm{ml}$ ) to the heifer 4 and 2 week before calving results in decrease in service pre conception and open days in the treated groups, however, gestation length remain same among the groups. Ganie et al., (2014) observed that supplementation of $0.2 \mathrm{ppm}$ sodium selenite in the diet of murrah heifer for 120 day results in reduction in age at first calving and higher conception rate as compared to control. Similarly, Arechiga et al., (1998) reported that service per conception and service period were significantly decreased in the dairy cows administered with single intramuscular injection of vitamin $\mathrm{E}$ (200 mg)and sodium selenite (50 mg)postpartum. Qureshi et al., (2010) reported that increase in conception rate and estrus rate following $50 \mathrm{mg}$ selenium administration in buffaloes this may be due to the positive effect of selenium on post-partum uterine involution results in improvement of reproductive performance.

Khatti et al., (2017) reported that supplementation of $\mathrm{Se}(0.3 \mathrm{mg} / \mathrm{kg} \mathrm{DM})$ and Vitamin E (80 IU/kg DM) along with $20 \%$ additional allowance for energy to the advance pregnant cross bred cow results in significantly higher pregnancy rate and early resumption of postpartum estrus in treated animals as compared to control. Kamada (2017) reported that postpartum plasma progesterone concentrations was higher in selenium yeast (300 mg Se, $10 \mathrm{~g}$ yeast) supplemented Holstein cow the control.

\section{Zinc}

Zinc ( $\mathrm{Zn})$ is an essential trace element important for every living being (Suttle, 2010). It is an important component of various metalloenzymes and activator of more than 300 enzymes in the animal body (Salim et al., 2012). Zinc acts as an essential component of 
antioxidant defense system (Bao and Choct, 2009), plays an important role in thyroid metabolism (Mullur et al., 2014) and is also required for normal activity of immune system (Tsai et al., 2016).It play important role in configuration of RNA and DNA by formation of zinc fingers which is essential for the binding of steroid receptor complex to DNA (Freedman, 1992). Zn influence pregnancy by modulating the action of insulin-like growth factors (IGFs) at the cellular level. Insulin-like growth factors are known to be potent stimulators of tissue differentiation and cell proliferation. These growth factors are present in high levels within the uterus of several livestock species during early pregnancy (Ko et al., 1991) and may be important in uterine remodelling during the time of embryonic implantation (IGF-I) and fetal development (IGF-II), as well as for conceptus growth in general. In male testes have higher amount of zinc as compared to liver and kidney. I t has been observed that zinc deficiency can cause severe damage to the testes such as atrophy of the testicular tubules and the inhibition of spermatid differentiation. Abdel et al., (2011) reported that supplementation of different levels of inorganic zinc oxide (50-150 ppm) in Baladi ewe significantly increased the incidence of oestrus, pregnancy, lambing rates and resulted in shorter onset of oestrus as compared to the control group.Kundu et al., (2014) reported that supplementation of 50 and $100 \mathrm{ppm}$ zinc oxide to Teressa goat results insignificantly higher incidence of oestrus (33\%), pregnancy rate $(12 \%)$, kidding rate $(5 \%)$ and resulted in shorter onset (8 days) of oestrus as compared to the control.

\section{Copper}

$\mathrm{Cu}$ first shown to essential for growth and $\mathrm{Hb}$ formation in 1928 It is also a critical functional component of a number of enzymes known as cuproenzymes (cytochrome c oxidase, Superoxide dismutase,
Ceruloplasmin) (Coppen et al., 1998). It has been established that $\mathrm{Cu}$ is related to synthesis and secretion of the hypophysiary hormones, modulating the capacity for the liberation of the luteinizing hormone (LH). (Corbellini, 1998). The administration of gonadotrophic releasing hormone $(\mathrm{GnRH})$ in rats with normal levels of $\mathrm{Cu}$ increased the liberation of $\mathrm{LH}$ and follicle stimulating hormone (FSH) from the hypophysis, when compared to hypocupremic animals, probably due to $\mathrm{Cu}$ stimulating the $\mathrm{GnRH}$ receptors in the hypophysis (Kochman et al., 1997). However, it also has a role as an antioxidant, which may be an importance factor in maintaining reproductive performance. Juan et al., (2012) reported supplementation of $\mathrm{Cu}$ EDTA in hypocupric animals resulted in higher onset of estrus and pregnancy rate this improvement in the reproductive performance is mainly due to increase in gonadal hormonal output under the influence of GnRH.

\section{Manganese}

Fifth most abundant metal on earth shown to be essential for growth and fertility it was first classified as an essential trace element in 1931. A deficiency of $\mathrm{Mn}$ results in poor growth and impaired reproduction, which is characterized by testicular atrophy in males and impaired ovulation in females. It play important role in reproductive cycle of animals by virtue of its role in steriodogenesis (cofactor for an enzymes mevalonate kinase and fernesyl pyrophosphate synthase required for cholesterol biosynthesis) Mn may have a role in initiating estradiol secretion by the conceptus as the signal for pregnancy recognition in pigs. Alternatively, Mn may play a role in progesterone secretion because concentrations of $\mathrm{Mn}$ in the $\mathrm{CL}$ of ewes increased between 4 and 11 days (Hurley and Doane, 1989). 


\section{Iodine}

Necessary for thyroid hormone synthesis that regulate BMR and energy metabolism Reproductive disorder in iodine deficiency due to thyroid gland dysfunction in the dam, embryo or fetus, which in the last two can cause embryonic death, abortion, stillbirth or weak goitrous calves (suttle, 2010). Iodine is required for thyroxine synthesis which is a general metabolic regulator and, in particular, a regulator of mitochondrial activity and lack of of thyroxine is associated with non-specific signs of poor growth, loss of libido and inhibition of oestrous behaviour hence affect the reproductive performance of animals. Sargison et al., (1998), reported that supplementation of iodine to ewes before mating increase the twining rate this occur due to increase in ovulation following iodine supplementation.

\section{Chromium}

$\mathrm{Cr}$ in form of dinicolinic acid-glutathione complex (GTF) - vital for carbohydrate metabolism chromium has an improving effect on insulin binding and increases the number of insulin receptors on the cell surface and sensitivity of pancreatic $\beta$-cells together with an overall increase of insulin-sensitivity (Anderson, 1997).The mechanism of effect of $\mathrm{Cr}$ on reproduction functions has not been known. One of the theories (Lindemann, 1996) assumes reproduction can be affected by changing sensitivity to insulin. Most attention has been devoted to studying the effect of $\mathrm{Cr}$ on reproduction in pigs. $\mathrm{Cr}$ supplementation to sow during the reproduction cycle has had a positive effect on the size of the litter at birth as well as the weight at weaning (Lindemann et al., 1995). Also retention of foetal membranes was significantly reduces in dairy cows supplemented with chromium picolinate this may be due to reduction in concentration of cortisol (Villalobos et al., 1997).
In conclusion, trace minerals have profound effect on fertility of animals these are required for synthesis of reproductive steroid hormones and optimum cellular enzyme function which are necessary for reproductive efficiency regular feeding of these trace minerals is very important for the achievement of opium reproductive health of animals.

\section{References}

Bennetts, H.W., Chapman, F.E. 1937. Copper deficiency in sheep in Western Australia: a preliminary account of the aetiology of enzootic ataxia of lambs and an anaemia of ewes. Australian Veterinary Journal.13:138- 149.

Allmang, C. and Krol, A. 2006.Selenoprotein synthesis: UGA does not end the story. Biochemie.88, 1561-1571.

Arechiga C.F., Vazquez-Flores S., Hernandez-Ceron J., Porras P., McDowell L.R. and Hansen P.J. 1998.Effect of injection of beta carotene or vitamin $\mathrm{E}$ and selenium on fertility of lactating dairy cow. Theriogenology. 50: 65-76.

Bao, Y.M. and Choct, M. 2009. Trace mineral nutrition for broiler chickens and prospects of application of organically complexed trace minerals: a review. Animal Production Science.49: 269282.

Coppen D.E. and Davies N.T.1988.Studies on the roles of apotransferrin and ceruloplasmin on iron absorption in copper deficient rats using an isolated vascularly- and luminally-perfused intestinal preparation. British Journal of Nutrition 60:361-373.

Corbellini C.N.1998. Influence of micronutrients in the fertility of dairy cows] (part II).Revue de Médecinen Vétérinaire. 79:231-236.

Freedman, L.P. 1992. Anatomy of the steroid 
receptor zinc finger region. Endocrine Reviews. 13:129-145.

Gaine A. Ajaz., Baghel R.P.S., Mudgal V., Aarif O. and Sheikh G.C. 2014.Effect of selenium supplementation on reproductive performance and hormonal profile in buffalo heifers, Indian Journal of Animal.Research. 48(1): 27-30.

Hurley, W.L. and Doane, R.M. 1989. Recent development in the roles of vitamins and minerals in reproduction. Journal of Dairy Science 72: 784-804.

Kamada, H. 2017.Effects of selenium-rich yeast supplementation on the plasma progesterone levels of postpartum dairy cows. Asian-Australaian Journal of Animal Science.30(3):347-354.

Khatti, A., Mehrotra, S., Patel, P.K.,, Singh, G.,, Maurya, V.P.,, Mahla, A.S., Chaudhari, R.K., Das, G.K., Singh, M., Sarkar, M., Kumar, H. and Krishnaswamy, $\quad$ N, 2017. Supplementation of vitamin E, selenium and increased energy allowance mitigates the transition stress and improves postpartum reproductive performance in the crossbred cow. Theriogenology.104:142-148.

Ko, Y., Lee, C.Y., Ott, T.L., Davis, M.A., Simmen, R.C.M., Bazer, F.W. and Simmen, F.A.1991. Insulin-like growth factors in sheep uterine fluids: concentrations and relationship to ovine trophoblast protein-1 production during early pregnancy. Biology of Reproduction. 45(1):135-42.

Kochman K., Gajewska A., Kochman H., Kozlowski H., Masiukiewicz E. and Rzeszotarska B. 1997. Binding of $\mathrm{Cu} 2+, \quad \mathrm{Zn} 2+, \quad$ and $\mathrm{Ni} 2+-\mathrm{GnRH}$ complexes with the rat pituitary receptor. Journal of Inorganic Biochemsitry. 65: 277-279.

Kundu, M.S., De, A.K., Jeyakumar, S.,
Sunder, J, Kundu, A. and Sujatha, T. 2014.Effect of zinc supplementation on reproductive performance of Teressa goat. Veterinary World 7:380383.

Lindemann M.D. 1996.Organic chromium the missing link in farm animal nutrition? Feeding Times. 1: 8-16.

Lindemann M.D., Harper A.F. and Kornegay E.T. 1995.Further assessment of the effects of supplementation of chromium from chromium picolinate on fecundity in swine. Journal of Animal Science, 73: 185

Moeini M.M., Karami H. and Mikaeilli E. 2009 Efeect of selenium and vitamin E supplementation during the late pregnancy on reproductive indices and milk production in heifers, Animal Reproduction Science. 114:109-114.

Mullur, R., Liu, Y.Y. and Brent, G.A. 2014. Thyroid hormone regulation of metabolism. Physiological Review. 94, 355-382.

Qureshi, Z. I., Siddiq, M.,.Lodhi, L. A., Muhammad G. and Jamil, $\mathrm{H}$. 2010.Effect of Vitamin E-Selenium Administration during Late Gestation on Productive and Reproductive Performance in Dairy Buffaloes and on Growth Performance of their Calves. Pakistan Veterinary Journal.30(2): 83-86.

Salim, H.M., Lee, H.R., Jo, C., Lee, S.K. and Lee, B.D. 2012. Effect of sex and dietary organic zinc on growth performance, carcass traits, tissue mineral content, and blood parameters of broiler chickens. Biological Trace Element Research. 147:120-129.

Sargison, N.D., West, D.M. and Clark, R.G. 2011.The effect of iodine deficiency on ewe fertility and perinatal lamb mortality, New Zealand Veterinary Journal. 46(2): 72-75.

Spallholz, J.E. 1990. Selenium and 
glutathione peroxidase: essential nutrient and antioxidant component of the immune system. Advances in Experimental Medicine and Biology. 262:145-158.

Suttle, N.F. 2010.Mineral Nutrition of Livestock, 4th ed. CABi Publishing, USA.

Tsai, Y.H., Mao, S.Y., Li, M.Z., Huang, J.T. and Lien, T.F. 2016. Effects of nanosize zinc oxide on zinc retention, eggshell quality, immune response and serum parameters of aged laying hens. Animal Feed Science and Technology. 213, 99-107

Villalobos, J.A. F., Romero, C.R., Tarrago, M.R. C. and Rosado, A. 1997.Supplementation with chromium picolinate reduces the incidence of placenta retention in dairy cows Canadian Journal of Animal Science, 77:329-330

\section{How to cite this article:}

Sandeep Uniyal, K. Ashwin, Alok Mishra, Jatin Kumar Sahoo and Varsha Paladan. 2018. Importance of Micro Minerals in Reproductive Performance of Farm Animals. Int.J.Curr.Microbiol.App.Sci. 7(07): 3584-3589. doi: https://doi.org/10.20546/ijcmas.2018.707.417 